\title{
Relative Salt Tolerance of 22 Pomegranate (Punica granatum) Cultivars
}

\author{
Youping Sun \\ Department of Plants, Soils and Climate, Utah State University, 4820 Old \\ Main Hill, Logan, UT 84322
}

\section{Genhua Niu ${ }^{1}$}

Department of Horticultural Sciences, Texas A\&M AgriLife Research Center at El Paso, Texas A\&M University System, 1380 A\&M Circle, El Paso, TX 79927

\author{
Joseph G. Masabni \\ Department of Horticultural Sciences, Texas A\&M AgriLife Extension, Texas \\ A\&M University System, 1710 FM 3053 N, Overton, TX 75684
}

\section{Girisha Ganjegunte \\ Department of Soil and Crop Sciences, Texas A\&M AgriLife Research Center at El Paso, Texas A\&M University System, 1380 A\&M Circle, El Paso, TX 79927 \\ Additional index words. chloride, mineral nutrition, sodium exclusion, salinity}

\begin{abstract}
A greenhouse experiment was conducted to determine the relative salt tolerance of pomegranate (Punica granatum) cultivars. Twenty-two pomegranate cultivars were irrigated weekly with a saline solution at an electrical conductivity (EC) of $10.0 \mathrm{dS} \cdot \mathrm{m}^{-1}$ for 4 weeks and subsequently with a saline solution at an EC of $15.0 \mathrm{dS} \cdot \mathrm{m}^{-1}$ for another 3 weeks (salt treatment). Another group of uniform plants was watered with a nutrient solution without additional salts at an EC of $1.2 \mathrm{dS} \cdot \mathrm{m}^{-1}$ (control). No visual foliar salt damage (leaf burn, necrosis, or discoloration) was observed during the entire experimental period; however, salt treatment impacted pomegranate growth negatively, with a large variation among cultivars. Salt treatment reduced shoot length by $25 \%$ and dry weight (DW) by $32 \%$ on average for all cultivars. Cluster analysis classified the 22 tested pomegranate cultivars in two groups. The group consisting of 'Arturo Ivey', 'DeAnda', 'Kazake', 'Russian 8', 'Apseronski', 'Purple Heart', 'Carolina Vernum', 'Chiva', 'Kunduzski', 'Larry Ceballos 1', 'ML', 'Salavatski', 'Spanish Sweet', and 'Wonderful' was more salt tolerant than the group including 'Al-Sirin-Nar', 'Kandahar', 'SurhAnor', 'Early Wonderful', 'Angel Red', 'Ben Ivey', 'Utah Sweet', and 'Mollar'. The sodium ( $\mathrm{Na}$ ) concentration in the leaf tissue of all 22 pomegranate cultivars was less than $1 \mathrm{mg} \cdot \mathrm{g}^{-1}$ on a DW basis. All pomegranate cultivars in the salt treatment had an average leaf chloride (CI) content of $10.03 \mathrm{mg} \cdot \mathrm{g}^{-1} \mathrm{DW}$ - an increase of $17 \%$ from the control. These results indicate that pomegranate plants have a strong capability to exclude Na and $\mathrm{Cl}$ accumulation in leaf tissue. In conclusion, the pomegranate plant is very tolerant to saline water irrigation up to an $\mathrm{EC}$ of $15 \mathrm{dS} \cdot \mathrm{m}^{-1}$ with little foliar salt damage and a slight growth reduction. Investigation is needed to determine the effects of saline water on the fruit yield and nutritional quality of pomegranate.
\end{abstract}

Pomegranate (Punica granatum, Lythraceae) is a bushy shrub or small tree native to Iran to the Himalayas in northern India. It has been cultivated since ancient times throughout the Mediterranean regions of Asia, Africa, and Europe. The fruit is rich in nutrition, with a unique flavor and taste, and medicinal properties. Recent scientific findings corroborate the traditional use of the pomegranate as a medical remedy for its antimicrobial properties and for its health benefits, such as the ability to reduce blood pressure and to act against serious diseases such as diabetes and cancer (Holland et al., 2009). Increased public awareness of the benefit of the pomegranate, particularly in the western world, has led to
Mediterranean countries, and the southwestern United States. Saline brackish groundwater, treated municipal or industrial effluents, and recycled agricultural runoff water are the major alternative water sources for crop irrigation in many regions of the world, including those growing pomegranate (Qadir et al., 2008). These water sources often contain high salt levels that are detrimental to many species. Salt damage depends on the levels of salts and the degree of salt tolerance of crops. Therefore, the use of alternative waters for irrigation requires an adequate understanding of how salts impact plant performance and soil characteristics.

Limited literature shows that pomegranate is relatively tolerant to salt stress, with variations among cultivars (Bhantana and Lazarovitch, 2010; El-Khawaga et al., 2013; Okhovatian-Ardakani et al., 2010). 'MalasSaveh' pomegranate is less tolerant than 'Shishe-Kab' (Khayyat et al., 2014). Irrigation with saline groundwater at $6.0 \mathrm{dS} \cdot \mathrm{m}^{-1}$ increased $\mathrm{Na}$ and $\mathrm{Cl}$ accumulation in leaves; reduced growth, flowering, and yield; and increased incidence of fruit cracking but did not change the total sugar and acidity percentages of fruit in 7-year-old 'Manfalouty', 'Wonderful', and 'Nab-Elgamal' pomegranates, with different responses to saline water irrigation among cultivars (El-Khawaga et al., 2013). 'Malas Shirin' pomegranate was tolerant up to $40 \mathrm{~mm}$ sodium chloride $(\mathrm{NaCl})$ in 1:1 sand-perlite medium irrigated with complete Hoagland's solution (Naeini et al., 2006). Okhovatian-Ardakani et al. (2010) compared 10 Iranian commercial cultivars in a pot experiment irrigated with saline water at three levels of salinity $(4,7$, or $10 \mathrm{dS} \cdot \mathrm{m}^{-1}$ ) and found that salt tolerance is cultivar dependent, based on vegetative growth and tissue $\mathrm{Na}$ and $\mathrm{Cl}$ concentrations. However, salt tolerance of many existing cultivars in the United States is unknown. Identifying salt-tolerant cultivars is of great importance in pomegranate production. The aim of this study was to determine the relative salt tolerance of 22 pomegranate cultivars and their morphologic and physiologic responses to saline water irrigation in greenhouse conditions.

\section{Materials and Methods}

Plant materials. On 12 Mar. 2014, hardwood cuttings $(\approx 15 \mathrm{~cm})$ in RL98 Ray Leach Cone-tainers (SC10 Super, Stuewe and Sons., Inc., Tangent, OR; diameter, $3.8 \mathrm{~cm}$; depth, $21 \mathrm{~cm}$; volume, $164 \mathrm{~mL}$ ) were received from Marcelino's Nursery (Tornillo, TX). On 5 May 2014, rooted cuttings were transplanted in 5-L treepots $(\mathrm{CP} 512 \mathrm{CH}$, Stuewe and Sons., Inc.; width, $12.7 \mathrm{~cm}$; height, 30.5 $\mathrm{cm})$ containing commercial substrate Metro-Mix $902(50 \%$ to $60 \%$ composted bark, Canadian sphagnum peatmoss, vermiculite and coarse perlite, starter nutrient charge with gypsum and slow-release nitrogen, and dolomitic limestone; SunGro ${ }^{\circledR}$, Agawam, MA). All plants were grown in a greenhouse in El Paso, TX (lat. 31 $41^{\prime} 45^{\prime \prime} \mathrm{N}$, long. $106^{\circ} 16^{\prime} 54^{\prime \prime} \mathrm{W}$; elevation, $1139 \mathrm{~m}$ ) for 3 months 
and irrigated with a nutrient solution at an EC of $1.2 \pm 0.1 \mathrm{dS} \cdot \mathrm{m}^{-1}$ (mean and SD). The nutrient solution was prepared by adding $15 \mathrm{~N}-2.2 \mathrm{P}-$ 12.5K (Peters 15-5-15 Ca-Mg Special; Scotts, Marysville, $\mathrm{OH})$ to reverse osmosis water at a nitrogen concentration of $150 \mathrm{mg} \cdot \mathrm{L}^{-1}$.

Treatments. On 5 Aug. 2014, all plants were pruned to $30 \mathrm{~cm}$ tall. One week later (i.e., 11 Aug.), uniform plants were chosen and assigned to two groups, and treatment was initiated. One group of plants was irrigated weekly with a saline solution at an $\mathrm{EC}$ of $10.0 \mathrm{dS} \cdot \mathrm{m}^{-1}$ (actual EC is $9.9 \pm 0.4$ $\mathrm{dS} \cdot \mathrm{m}^{-1}$ ) for 4 weeks and subsequently with a saline solution at EC $15.0 \mathrm{dS} \cdot \mathrm{m}^{-1}$ (actual EC is $14.9 \pm 0.6 \mathrm{dS} \cdot \mathrm{m}^{-1}$ ) for 3 more weeks (salt treatment). This was because plants irrigated with saline solution did not show any damage. A greater salinity treatment was needed to distinguish the differences among the 22 cultivars. Another group of plants was watered with the aforementioned nutrient solution without additional salts (control). Saline solutions at an EC of $10 \mathrm{dS} \cdot \mathrm{m}^{-1}$ and $15 \mathrm{dS} \cdot \mathrm{m}^{-1}$ were prepared by adding $57.2 \mathrm{~mm}$ $\mathrm{NaCl}$ and $28.7 \mathrm{~mm}$ calcium chloride $\left(\mathrm{CaCl}_{2}\right)$, and $86.4 \mathrm{~mm} \mathrm{NaCl}$ and $43.3 \mathrm{~mm} \mathrm{CaCl}_{2}$, respectively, to the nutrient solution. This mixture was used because $\mathrm{NaCl}$ is the common salt in reclaimed water (Niu and Cabrera, 2010), and $\mathrm{CaCl}_{2}$ forestalls potential calcium deficiencies (Carter and Grieve, 2006). Both nutrient and saline solutions were prepared in 100-L tanks with EC confirmed using an EC meter (Model B173; Horiba, Ltd., Kyoto, Japan) before irrigation. Between treatment solutions, plants were irrigated with the nutrient solution whenever the substrate surface became dry. Irrigation frequency varied with environmental condition and treatment. For example, plants at a high salinity level used less water and needed irrigation less often compared with those plants in the control. At each irrigation, plants were irrigated with $1 \mathrm{~L}$ treatment solution/plant, resulting in a leaching fraction of $\approx 29 \pm 11 \%$.

Greenhouse environmental conditions. The average air temperature in the greenhouse was $30.9 \pm 5.2^{\circ} \mathrm{C}$ during the day and $23.0 \pm 4.3{ }^{\circ} \mathrm{C}$ at night during the entire experimental period. The average daily light

Received for publication 6 July 2018. Accepted for publication 13 Aug. 2018.

This research is supported in part by the Agricultural Research Service, the United States Department of Agriculture (USDA), National Institute of Food and Agriculture Hatch project TEX090450, and Texas A\&M AgriLife Research.

We appreciate the in-kind support of plant materials from Marcelino's Nursery, Tornillo, TX.

The content is solely the responsibility of the authors and does not necessarily represent the official views of the funding agencies. Mention of a trademark, proprietary product, or vendor does not constitute a guarantee or warranty of the product by the USDA and does not imply its approval to the exclusion of other products or vendors that also may be suitable.

${ }^{1}$ Corresponding author. E-mail: gniu@ag.tamu.edu. integral was $16.3 \pm 3.2 \mathrm{~mol} \cdot \mathrm{m}^{-2} \cdot \mathrm{d}^{-1}$, and the average relative humidity was $41.4 \pm 17.2 \%$.

Leachate EC. Leachate EC was determined using the pour-through method according to Cavins et al. (2008). In brief, a saucer was placed under the container that had drained for at least $30 \mathrm{~min}$ right after treatment solution was applied. A total of $100 \mathrm{~mL}$ distilled water was poured on the surface of the substrate to get leachate in the saucer. The leachate solution was collected and tested using an EC meter. One plant per treatment per cultivar was chosen for measurement each time after treatment solutions were applied. Leachate EC readings were averaged across cultivars.

Growth parameters. At the end of the experiment, plant height (measured in centimeters) was recorded from the pot rim to the top growing point. New growth of shoots (visibly distinguishable from the old growth before pruning) were harvested, and the length of all new shoots $(>5 \mathrm{~cm})$ was measured as shoot length. Then, all leaves of the new shoots were separated from the stems. Both leaves and stems were oven-dried at $70^{\circ} \mathrm{C}$ for $7 \mathrm{~d}$, and the leaf and stem DW was determined.

Foliar salt damage evaluation. One week before harvest, foliar salt damage was rated visually using a reference scale from 0 to 5 , where $0=$ dead, $1=$ more than $90 \%$ foliar damage (leaf burn, necrosis, or discoloration), $2=$ moderate $(50 \%$ to $90 \%)$ foliar damage, $3=$ slight (less than 50\%) foliar damage, $4=$ good quality with minimal foliar damage, and $5=$ excellent with no foliar damage (Sun et al., 2015b). The foliar salt damage visual rating did not account for plant size.

Chlorophyll fluorescence and performance index. Maximal photochemical efficiency $\left(\mathrm{F}_{\mathrm{v}} / \mathrm{F}_{\mathrm{m}}\right)$ and performance index $(\mathrm{PI})$ were measured according to Strasser et al. (2000, 2004) using a Hansatech Pocket PEA chlorophyll fluorimeter (Hansatech Instruments Ltd., Norfolk, UK) to examine the effect of elevated salinity on leaf photosynthetic apparatus of pomegranate plants 1 week before harvest. Healthy and fully expanded leaves of three plants per treatment per cultivar were chosen for the measurements. Measurements were taken on sunny days between 0900 and $1600 \mathrm{HR}$, and plants were well watered to avoid drought stress. The leaves were dark-acclimated for at least 30 min before $F_{v} / F_{m}$ and PI measurements were acquired. Minimal fluorescence values in the dark-adapted state $\left(\mathrm{F}_{0}\right)$ were obtained by application of a low-intensity red light emitting diode light source $(627 \mathrm{~nm})$ at $50 \mu \mathrm{s}$, whereas maximal fluorescence values $\left(\mathrm{F}_{\mathrm{m}}\right)$ were measured after applying a saturating light pulse of $3500 \mu \mathrm{mol} \cdot \mathrm{m}^{-2} \cdot \mathrm{s}^{-1}$. The parameter $F_{j}$ is fluorescence intensity at the $\mathrm{jth}$ step at $2 \mathrm{~ms} ; \mathrm{V}_{\mathrm{j}}$ is relative variable fluorescence at $2 \mathrm{~ms}$ calculated as $\mathrm{V}_{\mathrm{j}}=\left(\mathrm{F}_{\mathrm{j}}-\mathrm{F}_{0}\right) /\left(\mathrm{F}_{\mathrm{m}}-\mathrm{F}_{0}\right) . \quad \mathrm{M}_{0}$ represents the initial slope of fluorescence kinetics, which can be derived from the equation $\mathrm{M}_{0}=4 \times\left(\mathrm{F}_{300 \mu \mathrm{s}}-\mathrm{F}_{0}\right) /\left(\mathrm{F}_{\mathrm{m}}-\mathrm{F}_{0}\right)$. Maximum quantum use efficiency $\left(\mathrm{F}_{\mathrm{v}} / \mathrm{F}_{\mathrm{m}}\right)$ of photosystem II (PS II) in the dark-adapted state was calculated as $F_{v} / F_{m}=\left(F_{m}-F_{0}\right) / F_{m}$. PI was calculated as follows (Strasser et al., 2000; Živčák et al., 2008):

$$
\mathrm{PI}=\frac{1-\left(\mathrm{F}_{0} / \mathrm{F}_{\mathrm{m}}\right)}{\mathrm{M}_{0} / \mathrm{V}_{\mathrm{j}}} \times \frac{\mathrm{F}_{\mathrm{m}}-\mathrm{F}_{0}}{\mathrm{~F}_{0}} \times \frac{1-\mathrm{V}_{\mathrm{j}}}{\mathrm{V}_{\mathrm{j}}} .
$$

Gas exchange. Leaf net photosynthesis $\left(\mathrm{P}_{\mathrm{n}}\right)$, stomatal conductance $\left(g_{\mathrm{S}}\right)$, and transpiration $(\mathrm{E})$ of three plants per treatment per cultivar were measured 1 week before harvest using a CIRAS-2 portable photosynthesis system (PP Systems, Amesbury, MA) with an automatic universal PLC6 broadleaf cuvette. A fully expanded leaf at the top of the plant was chosen for measurement. The environmental conditions within the cuvette were maintained at a leaf temperature of $25{ }^{\circ} \mathrm{C}$, a photosynthetic photon flux of $1000 \mu \mathrm{mol} \cdot \mathrm{m}^{-2} \cdot \mathrm{s}^{-1}$, and a carbon dioxide concentration of $375 \mu \mathrm{mol} \cdot \mathrm{mol}^{-1}$. Data were recorded when the environmental conditions and gas exchange parameters in the cuvette became stable. These measurements were taken on sunny days between 0900 and $1600 \mathrm{HR}$, and plants were well watered to avoid water stress.

Mineral analysis. Four pomegranate plants per cultivar per treatment were selected randomly to analyze leaf $\mathrm{Na}, \mathrm{Cl}$, calcium $(\mathrm{Ca})$, and potassium $(\mathrm{K})$ concentrations. All leaves of each plant were dried and ground with a stainless Wiley mill (Thomas Scientific, Swedesboro, NJ) to pass through a 40mesh screen. Powder samples were extracted with 2\% acetic acid (Fisher Scientific, Fair Lawn, $\mathrm{NJ}$ ) to determine $\mathrm{Cl}$ levels using the method described in Gavlak et al. (1994). The concentration of $\mathrm{Cl}$ was determined with an M926 Chloride Analyzer (Cole Parmer Instrument Company, Vernon Hills, IL). Powder samples were submitted to the Soil, Water and Forage Testing Laboratory at Texas A\&M University (College Station, TX) to determine $\mathrm{Na}, \mathrm{Ca}$, and $\mathrm{K}$ concentrations. In brief, powder samples were digested in nitric acid following the protocol described by Havlin and Soltanpour (1989). $\mathrm{Na}, \mathrm{Ca}$, and $\mathrm{K}$ in digested samples were analyzed by inductively coupled plasmaoptical emission spectrometry (SPECTRO Analytical Instruments Inc., Mahwah, NJ) and reported on a dry plant basis as described by Isaac and Johnson (1975).

Experimental design and statistical anal$y$ sis. A split-plot design with salinity treatment as the main plot and 22 cultivars as the subplot was used. As a result of plant material availability, four, five, or seven plants (replications) per treatment per cultivar were grown. Analysis of variance was used to test the effects of soil salinity and cultivar on plant growth. Means separation between treatments was conducted using Student's $t$ test.

Because of the large number of cultivars, measurements took 2 weeks to complete. To minimize differences caused by different days, measurements started by rep number across the cultivars and treatments. Relative shoot DW was calculated for each plant in salt treatment as: Relative shoot DW $(\%)=$ (Shoot DW in salt treatment/Shoot DW in 
control) $\times 100$. Similarly, relative values for height, shoot length, leaf DW, and stem DW were calculated. These relative values and visual scores were used as salt tolerance indices for hierarchical cluster analysis (Zeng et al., 2002). The dendrogram of the 22 pomegranate cultivars is based on the Ward linkage method and squared Euclidian distance on the means of the salt tolerance indices for six multivariate parameters, including visual scores and all relative growth data. All statistical analyses were performed using JMP (version 12; SAS Institute Inc., Cary, NC).

\section{Results}

Leachate EC. The average leachate EC for the control (nutrient solution at EC of 1.2 $\mathrm{dS} \cdot \mathrm{m}^{-1}$ ) ranged from 2.8 to $3.9 \mathrm{dS} \cdot \mathrm{m}^{-1}$ during the entire experimental period (Fig. 1). For salt treatment, the leachate EC increased from 10.5 to $23.4 \mathrm{dS} \cdot \mathrm{m}^{-1}$ (for EC values $>20 \mathrm{dS} \cdot \mathrm{m}^{-1}$, samples were diluted before the final measurement). The data indicated that more salts accumulated in the root zone of pomegranate plants irrigated with saline solution compared with nutrient solution.

Foliar salt damage and growth parameters. Regardless of cultivar, all pomegranate plants had no foliar salt damage (leaf burn, necrosis, or discoloration), with a visual score of 5 , during the entire experimental period (i.e., $66 \mathrm{~d}$; Tables 1 and 2). Salt treatment affected plant height, shoot length, leaf DW, stem DW, and shoot DW of all pomegranate cultivars, but no interactions between salinity and cultivar were observed (Table 1). This indicates that all pomegranate cultivars responded similarly to the saline solution applied in this study. Salt treatment did not inhibit the plant height of all pomegranate cultivars except 'Mollar', 'Purple Heart', and 'Russian 8' (Table 2). Of all tested cultivars, the average reduction in plant height was $6 \%$, with 'Mollar' having the greatest reduction of $14 \%$. Salt treatment reduced the shoot length of 'Arturo Ivey', 'AlSirin-Nar', 'DeAnda', 'Early Wonderful', 'Kandahar', 'Purple Heart', 'Russian 8', 'Surh-Anor', and 'Utah Sweet' pomegranate.

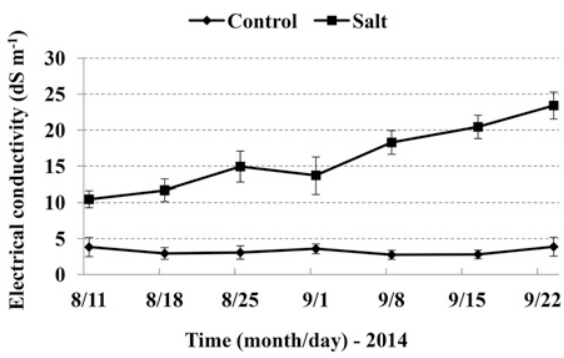

Fig. 1. Leachate electrical conductivity (EC) measured using the PourThru technique during the experimental period. Control represents a nutrient solution at an EC of $1.2 \mathrm{dS} \cdot \mathrm{m}^{-1}$, whereas Salt represents a saline solution at an EC of $10.0 \mathrm{dS} \cdot \mathrm{m}^{-1}$ for the first 4 weeks and $15.0 \mathrm{dS} \cdot \mathrm{m}^{-1}$ for the latter 3 weeks. Vertical bars represent sDs of 22 samples (cultivars) per treatment.
'Early Wonderful' pomegranate had the greatest reduction of $46 \%$, whereas 'ML' had the least reduction of $10 \%$. The average reduction of shoot length of all cultivars was $25 \%$.

Salt treatment decreased the leaf, stem, and shoot DW of 'Al-Sirin-Nar', 'Angel Red', 'Apseronski', 'DeAnda', 'Early Wonderful', 'Kandahar', 'Kazake', 'Purple Heart', 'Russian 8', 'Salavatski', 'SurhAnor', and 'Utah Sweet' (Table 3). Salt treatment also reduced the leaf DW of 'Carolina Vernum', and stem and shoot DW of 'Chiva'. Although no significant differences were observed for the remaining cultivars, salt treatment slightly decreased their leaf, stem, and shoot DW. The reductions of leaf, stem, and shoot DW on average for all cultivars were $32 \%, 32 \%$, and $32 \%$, respectively, with large variations among cultivars. The greatest reduction in leaf DW, stem DW, and shoot DW was 52\% for 'Al-Sirin-Nar', $49 \%$ for 'Kunduzski', and $48 \%$ for 'Al-SirinNar', respectively. The least reduction in leaf DW, stem DW, and shoot DW was $19 \%$ for 'Kunduzski', 21\% for 'Mollar', and 25\% for 'ML', respectively.

A dendrogram was developed using the means of the salt tolerance indices for six multivariate parameters including visual scores and relative height, shoot length, leaf DW, stem DW, and shoot DW of all pomegranate cultivars (Fig. 2). Two major clusters were identified. The cluster of 'Arturo Ivey', 'DeAnda', 'Kazake', 'Russian 8', 'Apseronski', 'Purple Heart', 'Carolina Vernum', 'Chiva', 'Kunduzski', 'Larry Ceballos 1', 'ML', 'Salavatski', 'Spanish Sweet', and 'Wonderful' was more salt tolerant than the other cluster of 'Al-Sirin-Nar', 'Kandahar', 'Surh-Anor', 'Early Wonderful', 'Angel Red', 'Ben Ivey', 'Utah Sweet', and 'Mollar'

Chlorophyll fluorescence, PI, and gas exchange. Salt treatment affected $\mathrm{F}_{\mathrm{v}} / \mathrm{F}_{\mathrm{m}}$, PI, $\mathrm{P}_{\mathrm{n}}, g_{\mathrm{S}}$, and E (Table 1). All parameters except $\mathrm{F}_{\mathrm{v}} / \mathrm{F}_{\mathrm{m}}$ were significant among cultivars, and no interactions occurred between salt treatment and cultivar. Salt treatment reduced the $F_{v} / F_{m}$ values of 'Al-Sirin-Nar' and 'Kunduzski' only (Table 4$)$. The averaged $\mathrm{F}_{\mathrm{v}} / \mathrm{F}_{\mathrm{m}}$ values for all pomegranate cultivars were 0.80 and 0.78 for the control and salt treatment, respectively. Salt treatment also reduced the PI value of 'Al-Sirin-Nar'. The mean PI values for all pomegranate cultivars were 3.31 and 2.46 for the control and salt treatment, respectively, with a $26 \%$ reduction.

The $\mathrm{P}_{\mathrm{n}}, g_{\mathrm{S}}$, and $\mathrm{E}$ of all pomegranate cultivars irrigated with saline solution were similar to those with nutrient solution with the exception of 'Apseronski' (Table 5). On average, the $\mathrm{P}_{\mathrm{n}}, g_{\mathrm{S}}$, and $\mathrm{E}$ of all pomegranate cultivars were $11.2 \mu \mathrm{mol} \cdot \mathrm{m}^{-2} \cdot \mathrm{s}^{-1}, \quad 237.2$ $\mathrm{mmol} \cdot \mathrm{m}^{-2} \cdot \mathrm{s}^{-1}$, and $3.8 \mathrm{mmol} \cdot \mathrm{m}^{-2} \cdot \mathrm{s}^{-1}$ for plants irrigated with nutrient solution, respectively; and $9.2 \mu \mathrm{mol} \cdot \mathrm{m}^{-2} \cdot \mathrm{s}^{-1}, 158.0 \mathrm{mmol} \cdot \mathrm{m}^{-2} \cdot \mathrm{s}^{-1}$, and $2.9 \mathrm{mmol} \cdot \mathrm{m}^{-2} \cdot \mathrm{s}^{-1}$ for plants irrigated with saline solution, respectively.

Mineral analysis. Salt treatment increased leaf $\mathrm{Na}$ concentration significantly by 3.2 , $3.3,5.1,2.8,18.8,6.3,8,0.97$, and 8.2 times for 'Al-Sirin-Nar', 'Angel Red', 'Kazake',
'Kunduzski', 'Russian 8', 'Salavatski', 'Surh-Anor', 'Utah Sweet', and 'Wonderful', respectively, compared with the control (Table 6). No significant difference in leaf $\mathrm{Na}$ concentration of the remaining 13 pomegranate cultivars was observed between control and salt treatment. The averaged leaf $\mathrm{Na}$ content of all tested pomegranate cultivars was 0.07 and $0.28 \mathrm{mg} \cdot \mathrm{g}^{-1} \mathrm{DW}$ for plants in the control and salt treatment, respectively. 'Angel Red' pomegranate in salt treatment had the greatest $\mathrm{Na}$ concentration of 0.71 $\mathrm{mg} \cdot \mathrm{g}^{-1} \mathrm{DW}$.

Salt treatment also increased leaf $\mathrm{Cl}$ concentration of 'Al-Sirin-Nar', 'Apseronski', 'Carolina Vernum', 'Kazake', 'Kunduzski', 'Mollar', and 'Russian 8' pomegranate by $51 \%, 33 \%, 16 \%, 32 \%, 35 \%, 42 \%$, and $37 \%$, respectively, compared with their respective controls (Table 6). The averaged leaf $\mathrm{Cl}$ concentration of all pomegranate cultivars was 8.56 and $10.03 \mathrm{mg} \cdot \mathrm{g}^{-1} \mathrm{DW}$ for plants in the control and salt treatment, respectively. 'Angel Red' pomegranate in salt treatment showed the greatest $\mathrm{Cl}$ content of $12.04 \mathrm{mg} \cdot \mathrm{g}^{-1} \mathrm{DW}$.

Saline solution prepared with $\mathrm{NaCl}$ and $\mathrm{CaCl}_{2}$ increased the leaf $\mathrm{Ca}$ concentration of 'Purple Heart', 'Russian 8', 'Salavatski', and 'Surh-Anor' pomegranate by 34\%, 64\%, $51 \%$, and $36 \%$, respectively (Table 6). However, leaf $\mathrm{Ca}$ concentration of 'Arturo Ivey', 'Al-Sirin-Nar', 'Angel Red', 'Apseronski', 'Ben Ivey', 'Chiva', 'Carolina Vernum', and 'Early Wonderful' pomegranate was less in salt treatment than in the control. No significant difference in the leaf $\mathrm{Ca}$ concentration between control and salt treatment was observed for the remaining 10 pomegranate cultivars. The averaged leaf $\mathrm{Ca}$ concentration of all pomegranate cultivars was 4.76 and $4.49 \mathrm{mg} \cdot \mathrm{g}^{-1} \mathrm{DW}$ for plants in the control and salt treatment, respectively.

Leaf $\mathrm{K}$ concentration decreased significantly with increasing EC in 'Carolina Vernum', 'Kazake', and 'Kunduzski' pomegranate (Table 6). Although leaf K content of 'Arturo Ivey', 'Al-Sirin-Nar', 'Apseronski', 'Ben Ivey', 'Chiva', 'DeAnda', 'Early Wonderful', 'Kandahar', 'Larry Ceballos 1 ', and 'ML' tended to decrease, no significant difference between control and salt treatment was observed. However, leaf $\mathrm{K}$ content of 'Purple Heart', 'Russian 8', 'Surh-Anor', 'Utah Sweet', and 'Wonderful' tended to increase, but no significant difference between control and salt treatment occurred.

\section{Discussion}

Salt accumulation in the substrate. To quantify the salinity levels throughout the experiment, we used the PourThru method (Cavins et al., 2008) to check the EC of the leachate solution, which is an indication of salt accumulation. More salts accumulated in the root zone of pomegranate plants irrigated with saline solution compared with those with nutrient solution (Fig. 1). El-Khawaga et al. (2013) also observed that saline 
Table 1. A summary of analysis of variance for the effects of salt treatment (Trt), cultivar (Cv), and their interactions on visual score, height, shoot length, leaf dry weight, stem dry weight, shoot dry weight, chlorophyll fluorescence $\left(\mathrm{F}_{\mathrm{v}} / \mathrm{F}_{\mathrm{m}}\right)$, performance index $(\mathrm{PI})$, net photosynthesis $\left(\mathrm{P}_{\mathrm{n}}\right)$, stomatal conductance $\left(g_{\mathrm{S}}\right)$, and transpiration (E) of 22 pomegranate cultivars that were grown and irrigated with nutrient solution or saline solution in the greenhouse.

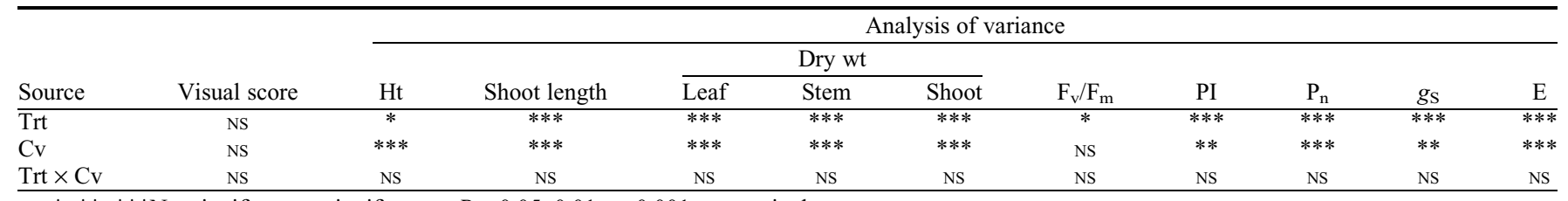

Ns, ***,***Nonsignificant or significant at $P<0.05,0.01$, or 0.001 , respectively.

Table 2. Visual score, height, and shoot length of 22 pomegranate cultivars irrigated with nutrient solution (Control) or saline solution (Salt). Reduction (\%) in height and shoot length was calculated as a percentage of the control.

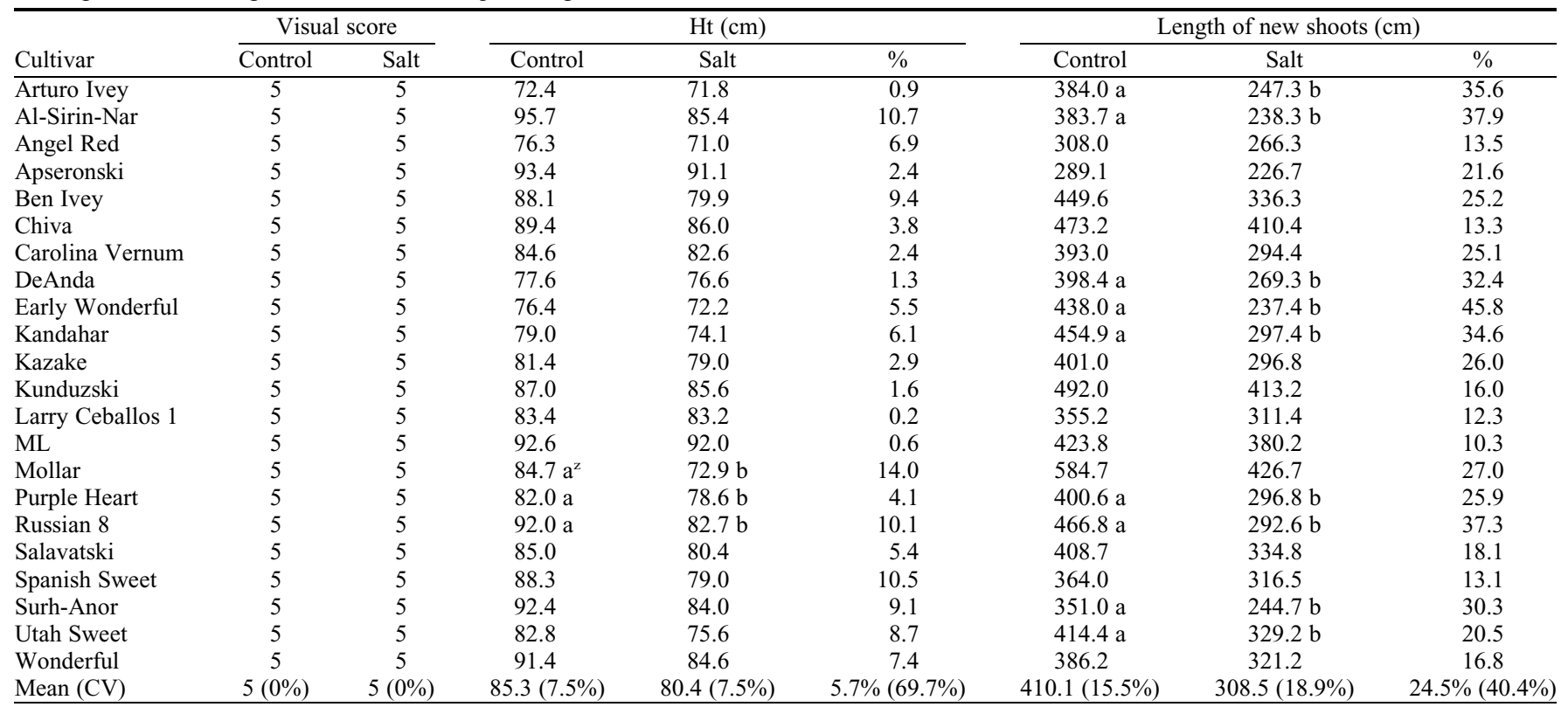

${ }^{\mathrm{z}}$ Means with different lowercase letters within a row for the same variable are significantly different between treatments by Student's $t$ test at $P<0.05$.

Table 3. Leaf, stem, and shoot dry weight (DW) of 22 pomegranate cultivars irrigated with nutrient solution (Control) or saline solution (Salt). Reduction (\%) in leaf, stem, and shoot DW was calculated as a percentage of the control.

\begin{tabular}{|c|c|c|c|c|c|c|c|c|c|}
\hline \multirow[b]{2}{*}{ Cultivar } & \multicolumn{3}{|c|}{ Leaf DW (g) } & \multicolumn{3}{|c|}{ Stem DW (g) } & \multicolumn{3}{|c|}{ Shoot DW (g) } \\
\hline & Control & Salt & $\%$ & Control & Salt & $\%$ & Control & Salt & $\%$ \\
\hline Al-Sirin-Nar & $23.6 \mathrm{a}$ & $11.4 \mathrm{~b}$ & 51.9 & $16.1 \mathrm{a}$ & $9.4 \mathrm{~b}$ & 41.4 & $39.7 \mathrm{a}$ & $20.8 \mathrm{~b}$ & 47.6 \\
\hline Ben Ivey & 26.3 & 18.7 & 29.2 & 19.0 & 12.0 & 36.8 & 45.3 & 30.7 & 32.3 \\
\hline Chiva & 27.6 & 21.1 & 23.6 & $22.9 \mathrm{a}$ & $14.8 \mathrm{~b}$ & 35.4 & $50.6 \mathrm{a}$ & $35.9 \mathrm{~b}$ & 29.0 \\
\hline Carolina Vernum & $21.9 \mathrm{a}^{\mathrm{z}}$ & $13.1 \mathrm{~b}$ & 40.1 & 18.0 & 12.1 & 32.6 & 39.9 & 25.2 & 36.7 \\
\hline Kandahar & $12.4 \mathrm{a}$ & $6.9 \mathrm{~b}$ & 44.5 & $14.9 \mathrm{a}$ & $9.2 \mathrm{~b}$ & 38.1 & $27.2 \mathrm{a}$ & $16.1 \mathrm{~b}$ & 40.9 \\
\hline Kazake & $21.4 \mathrm{a}$ & $16.4 \mathrm{~b}$ & 23.4 & $16.8 \mathrm{a}$ & $12.2 \mathrm{~b}$ & 27.6 & $38.2 \mathrm{a}$ & $28.6 \mathrm{~b}$ & 25.2 \\
\hline Kunduzski & 20.1 & 16.4 & 18.5 & 21.9 & 11.3 & 48.5 & 42.0 & 30.6 & 27.0 \\
\hline Larry Ceballos 1 & 23.7 & 18.3 & 22.6 & 16.0 & 11.4 & 28.6 & 39.7 & 29.7 & 25.1 \\
\hline ML & 23.4 & 17.8 & 24.1 & 18.9 & 14.1 & 25.2 & 42.3 & 31.9 & 24.5 \\
\hline Mollar & 24.5 & 14.2 & 41.9 & 14.1 & 11.2 & 20.5 & 38.6 & 25.5 & 34.0 \\
\hline Purple Heart & $21.5 \mathrm{a}$ & $13.8 \mathrm{~b}$ & 35.7 & $14.2 \mathrm{a}$ & $10.1 \mathrm{~b}$ & 28.6 & $35.7 \mathrm{a}$ & $23.9 \mathrm{~b}$ & 32.9 \\
\hline Wonderful & 23.8 & 17.6 & 26.2 & 18.0 & 12.8 & 28.7 & 41.8 & 30.4 & 27.1 \\
\hline Mean (CV) & $21.2(15.6 \%)$ & $14.4(22.8 \%)$ & $32.4 \%(28.5 \%)$ & $16.0(18.8 \%)$ & $10.7(18.5 \%)$ & $32.5 \%(21.4 \%)$ & $37.2(14.7 \%)$ & $25.3(20.0 \%)$ & $32.3 \%(20.3 \%)$ \\
\hline
\end{tabular}

${ }^{\mathrm{z}}$ Means with different lowercase letters within a row for the same variable are significantly different between treatments by Student's $t$ test at $P<0.05$.

groundwater irrigation at an $\mathrm{EC}$ of $1.8 \mathrm{dS} \cdot \mathrm{m}^{-1}$ and $6.0 \mathrm{dS} \cdot \mathrm{m}^{-1}$ raised the salt accumulation in the root zone at a soil depth of 60 to $90 \mathrm{~cm}$ from $3.7 \mathrm{dS} \cdot \mathrm{m}^{-1}$ to $4.8 \mathrm{dS} \cdot \mathrm{m}^{-1}$ and $7.7 \mathrm{dS} \cdot \mathrm{m}^{-1}$, respectively, when pomegranate plants were grown in sandy clay loam soil. In addition, salts accumulated less rapidly in this experiment compared with those reported previously (Sun et al., 2015b; Wu et al., 2016), 
which might result from different substrates used. Metro-Mix 902 with $50 \%$ to $60 \%$ composted bark was used in this experiment, whereas Metro-Mix 360 with $45 \%$ to $55 \%$ Canadian sphagnum peatmoss was used in others. Metro-Mix 902 may retain fewer salts and hold less water compared with MetroMix 360 because composted bark has a lesser cation exchange capacity and container capacity than peatmoss (Altland et al., 2014; Gabriel et al., 2009). This substrate could be suitable for long-term pomegranate production to prevent salt accumulation.

Salinity effect on growth. Salinity can inhibit plant growth and cause deleterious effects on plant foliage such as leaf burn, necrosis, or discoloration (Munns, 2002; Wahome et al., 2001). Previous studies have

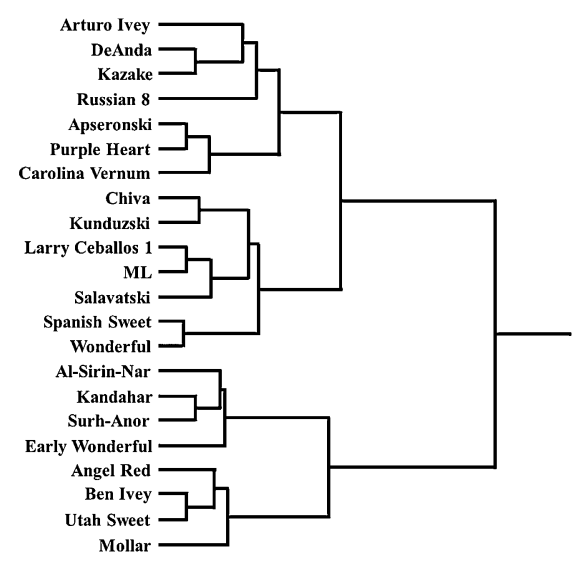

Fig. 2. The dendrogram of cluster analysis of 22 pomegranate cultivars based on the Ward linkage using squared Euclidian distance on means of multivariate parameters including visual scores and relative height, shoot length, leaf dry weight, stem dry weight, and shoot dry weight. shown that elevated salinity levels decrease leaf and shoot biomass in a variety of plant species (Cai et al., 2014; Niu and Rodriguez, 2006; Niu et al., 2013; Sun et al., 2013, 2015a, 2015b). Salt treatment decreased leaf, stem, and shoot DW significantly in all cultivars, with large variations among cultivars. However, all pomegranate cultivars had no foliar salt damage. In addition, shoot length reduced by $25 \%$ on average. These results are in line with previous work that consistently reported that increasing salinity level will inhibit pomegranate growth in terms of shoot length, leaf area, shoot biomass, or yield. Seven-year-old 'Manfalouty', 'Wonderful', and 'Nab-Elgamal' pomegranate grown in sandy clay loam soil and under environmental conditions in upper Egypt had greater reductions in growth, flowering, and yield, with greater fruit cracking, when they were irrigated with saline groundwater at an EC of $6.0 \mathrm{dS} \cdot \mathrm{m}^{-1}$ than at an EC of $1.8 \mathrm{dS} \cdot \mathrm{m}^{-1}$ (El-Khawaga et al., 2013). Naeini et al. (2006) reported that 'Malas Torsh' and 'Alak Torsh' pomegranate had reduced stem length, internode length and number, and leaf surface when irrigated with saline water spiked with 40,80 , or $120 \mathrm{Mm} \mathrm{NaCl}$. Net productivity and crop yield of pomegranate would be expected to reduce as growth reduction occurred as a result of saline water irrigation.

Salinity effect on photosynthetic apparatus. Salinity also impairs the plant photosynthetic apparatus (PS II) (Taiz and Zeiger, 2015). Salt treatment affected $F_{v} / F_{m}$, PI, $\mathrm{P}_{\mathrm{n}}, g_{\mathrm{S}}$, and $\mathrm{E}$, and all pomegranate cultivars showed similar responses to salt treatment. Salt treatment decreased the $\mathrm{F}_{\mathrm{v}} / \mathrm{F}_{\mathrm{m}}, \mathrm{PI}, \mathrm{P}_{\mathrm{n}}, \mathrm{E}$, and $g_{\mathrm{S}}$ of pomegranate cultivars by $2 \%, 25 \%, 18 \%, 34 \%$, and $23 \%$, respectively. This result indicated that salt treatment affected the photosynthetic appa- ratus of pomegranate. Khayyat et al. (2016) reported that the photosynthetic efficiency of 'Malas-e-Saveh' and 'Shishe-Kab' pomegranates was reduced under salinity stress. Hasanpour et al. (2015) also observed that salinity treatment decreased the chlorophyll index and chlorophyll fluorescence.

Salinity effect on mineral contents. Plants can adapt to salt stress through excluding or tolerating $\mathrm{Na}$ or $\mathrm{Cl}$ accumulation in their shoots (Munns and Tester, 2008). A total of $77 \%$ of pomegranate cultivars tested in our experiment increased or tended to increase the $\mathrm{Na}$ in leaf tissue when irrigated with saline solution; however, $\mathrm{Na}$ concentration of all 22 cultivars was less than $1 \mathrm{mg} \cdot \mathrm{g}^{-1}$. This result is similar to previous work done on pomegranate plants by Karimi and Hasanpour (2014, 2017), Khayyat et al. (2014, 2016), Naeini et al. (2004, 2006) and Okhovatian-Ardakani et al. (2010), who all observed an increase in $\mathrm{Na}$ in plant tissue with increasing $\mathrm{NaCl}$ concentration in irrigation water. This result indicates that pomegranate plants have greater ability to minimize tdoie transport of $\mathrm{Na}$ into the shoots to avoid foliar salt damage (Karimi and Hassanpour, 2014, 2017). Leaf Na content in pomegranate is similar to that in rose rootstocks (Rosa xhybrida 'Dr. Huey', $R$. $\times$ fortuniana, $R$. multiflora, and $R$. odorata) that experienced foliar salt damage (Niu and Rodriguez, 2008). But, leaf $\mathrm{Na}$ content in pomegranate is less than in other woody plants, such as Sophora secundiflora (Niu and Rodriguez, 2010) and Jatropha curcas (Niu et al., 2012).

On average, leaf $\mathrm{Cl}$ content of all pomegranate cultivars in salt treatment was 10.03 $\mathrm{mg} \cdot \mathrm{g}^{-1} \mathrm{DW}$, or a $17 \%$ increase compared with that of the control. Previous researchers have documented that mineral concentration of $\mathrm{Cl}$ in plant tissue increased with increasing

Table 4. Leaf chlorophyll fluorescence $\left(\mathrm{F}_{\mathrm{v}} / \mathrm{F}_{\mathrm{m}}\right)$, and performance index (PI) of 22 pomegranate cultivars irrigated with nutrient solution (Control) or saline solution (Salt). Reduction (\%) in $\mathrm{Fv} / \mathrm{Fm}$ and PI was calculated as a percentage of the control.

\begin{tabular}{|c|c|c|c|c|c|c|}
\hline \multirow[b]{2}{*}{ Cultivars } & \multicolumn{3}{|c|}{$\mathrm{F}_{\mathrm{v}} / \mathrm{F}_{\mathrm{m}}$} & \multicolumn{3}{|c|}{ PI } \\
\hline & Control & Salt & $\%$ & Control & Salt & $\%$ \\
\hline Arturo Ivey & 0.80 & 0.80 & 0.0 & 3.65 & 3.26 & 10.8 \\
\hline Al-Sirin-Nar & $0.80 \mathrm{a}^{\mathrm{z}}$ & $0.78 \mathrm{~b}$ & 3.5 & $3.22 \mathrm{a}$ & $1.10 \mathrm{~b}$ & 66.0 \\
\hline Angel Red & 0.79 & 0.79 & 0.4 & 3.39 & 2.82 & 16.8 \\
\hline Apseronski & 0.78 & 0.77 & 0.9 & 1.73 & 1.21 & 30.1 \\
\hline Ben Ivy & 0.80 & 0.79 & 1.7 & 4.14 & 3.26 & 21.1 \\
\hline Chiva & 0.80 & 0.78 & 2.5 & 3.62 & 3.05 & 15.8 \\
\hline Carolina Vernum & 0.80 & 0.78 & 2.1 & 4.37 & 2.98 & 31.9 \\
\hline DeAnda & 0.80 & 0.79 & 2.1 & 4.00 & 2.18 & 45.5 \\
\hline Early wonderful & 0.79 & 0.78 & 0.8 & 2.46 & 2.21 & 10.2 \\
\hline Kandahar & 0.79 & 0.79 & 0.8 & 3.21 & 2.16 & 32.6 \\
\hline Kazake & 0.81 & 0.81 & 1.6 & 3.50 & 3.44 & 1.8 \\
\hline Kunduzski & $0.81 \mathrm{a}$ & $0.77 \mathrm{~b}$ & 4.9 & 2.79 & 1.70 & 38.9 \\
\hline Larry Ceballos 1 & 0.80 & 0.80 & 0.4 & 3.89 & 2.46 & 36.9 \\
\hline $\mathrm{ML}$ & 0.80 & 0.79 & 1.3 & 2.95 & 2.37 & 19.8 \\
\hline Mollar & 0.78 & 0.78 & 0.0 & 2.77 & 2.46 & 11.1 \\
\hline Purple Heart & 0.80 & 0.80 & 0.4 & 3.80 & 3.26 & 14.1 \\
\hline Russian 8 & 0.80 & 0.76 & 4.6 & 3.64 & 2.06 & 43.5 \\
\hline Salavatski & 0.79 & 0.79 & 0.4 & 2.39 & 1.91 & 20.2 \\
\hline Spanish Sweet & 0.80 & 0.78 & 2.5 & 3.10 & 1.63 & 47.3 \\
\hline Surh-Anor & 0.79 & 0.78 & 1.7 & 2.66 & 2.24 & 15.8 \\
\hline Utah Sweet & 0.80 & 0.79 & 2.1 & 3.91 & 2.86 & 26.9 \\
\hline Wonderful & 0.81 & 0.79 & 1.7 & 3.60 & 3.70 & 2.7 \\
\hline Mean $(\mathrm{CV})$ & $0.80(1.1 \%)$ & $0.78(1.2 \%)$ & $1.7(81.9 \%)$ & $3.31(19.8 \%)$ & $2.46(28.7 \%)$ & $25.4(63.5 \%)$ \\
\hline
\end{tabular}

${ }^{\mathrm{z}}$ Means with different lowercase letters within a row for the same variable are significantly different between treatments by Student's $t$ test at $P<0.05$. 
Table 5. Leaf net photosynthesis $\left(\mathrm{P}_{\mathrm{n}}\right)$, stomatal conductance $\left(g_{\mathrm{S}}\right)$, and transpiration $(\mathrm{E})$ of 22 pomegranate cultivars irrigated with nutrient solution (Control) or saline solution (Salt). Reduction (\%) in $\mathrm{P}_{\mathrm{n}}, g_{\mathrm{S}}$, and $\mathrm{E}$ was calculated as a percentage of the control.

\begin{tabular}{|c|c|c|c|c|c|c|c|c|c|}
\hline \multirow[b]{2}{*}{ Cultivars } & \multicolumn{3}{|c|}{$\mathrm{P}_{\mathrm{n}}\left(\mu \mathrm{mol} \cdot \mathrm{m}^{-2} \cdot \mathrm{s}^{-1}\right)$} & \multicolumn{3}{|c|}{$g_{\mathrm{S}}\left(\mathrm{mmol} \cdot \mathrm{m}^{-2} \cdot \mathrm{s}^{-1}\right)$} & \multicolumn{3}{|c|}{$\mathrm{E}\left(\mathrm{mmol} \cdot \mathrm{m}^{-2} \cdot \mathrm{s}^{-1}\right)$} \\
\hline & Control & Salt & $\%$ & Control & Salt & $\%$ & Control & Salt & $\%$ \\
\hline Al-Sirin-Nar & 8.5 & 8.5 & 0.7 & 149.4 & 138.8 & 7.1 & 2.8 & 2.7 & 2.5 \\
\hline Ben Ivy & 11.2 & 8.2 & 26.7 & 203.3 & 127.0 & 37.5 & 3.6 & 2.6 & 26.2 \\
\hline Chiva & 12.3 & 9.5 & 22.4 & 319.5 & 146.7 & 54.1 & 4.5 & 2.9 & 35.5 \\
\hline Carolina Vernum & 11.5 & 9.8 & 15.0 & 284.7 & 159.0 & 44.1 & 4.1 & 3.2 & 21.9 \\
\hline Kandahar & 10.2 & 9.8 & 3.9 & 210.0 & 138.0 & 34.3 & 3.5 & 2.9 & 17.0 \\
\hline Kazake & 8.5 & 6.2 & 27.9 & 154.0 & 92.0 & 40.3 & 2.9 & 2.1 & 26.9 \\
\hline Kunduzski & 11.7 & 11.5 & 1.1 & 247.3 & 217.0 & 12.2 & 3.9 & 3.7 & 6.7 \\
\hline Larry Ceballos 1 & 12.2 & 11.7 & 3.7 & 233.3 & 231.0 & 1.0 & 3.9 & 3.9 & 1.0 \\
\hline ML & 11.7 & 11.2 & 3.7 & 266.7 & 251.2 & 5.8 & 3.9 & 3.8 & 1.9 \\
\hline Mollar & 14.9 & 12.2 & 18.0 & 343.8 & 258.5 & 24.8 & 4.7 & 4.0 & 16.6 \\
\hline Purple Heart & 12.5 & 9.8 & 21.7 & 250.4 & 176.3 & 29.6 & 4.2 & 3.1 & 26.6 \\
\hline Wonderful & 9.6 & 9.2 & 4.4 & 163.7 & 150.3 & 8.2 & 3.1 & 2.9 & 9.2 \\
\hline Mean $(\mathrm{CV})$ & $11.2(16.0 \%)$ & $9.2(20.8 \%)$ & $18.1(60.6 \%)$ & $238.4(27.1 \%)$ & $156.8(33.7 \%)$ & $33.6(50.4 \%)$ & $3.8(17.3 \%)$ & $2.9(22.1 \%)$ & $23.4(53.4 \%)$ \\
\hline
\end{tabular}

${ }^{\mathrm{z}}$ Means with different lowercase letters within a row for the same variable are significantly different between the treatments by Student's $t$ test at $P<0.05$.

Table 6. Leaf sodium $(\mathrm{Na})$, calcium $(\mathrm{Ca})$, chloride $(\mathrm{Cl})$, and potassium $(\mathrm{K})$ concentrations of pomegranate cultivars irrigated with nutrient solution $(\mathrm{Control})$ or saline solution (Salt).

\begin{tabular}{|c|c|c|c|c|c|c|c|c|}
\hline \multirow{2}{*}{ Cultivar } & \multicolumn{8}{|c|}{ Mineral concn (mg/g DW) } \\
\hline & \multicolumn{2}{|c|}{$\mathrm{Na}$} & \multicolumn{2}{|c|}{$\mathrm{Cl}$} & \multicolumn{2}{|c|}{$\mathrm{Ca}$} & \multicolumn{2}{|c|}{$\mathrm{K}$} \\
\hline Arturo Ivey & 0.12 & 0.11 & 10.07 & 11.39 & $5.14 \mathrm{a}$ & $3.16 \mathrm{~b}$ & 21.35 & 20.48 \\
\hline Angel Red & $0.17 \mathrm{~b}$ & $0.71 \mathrm{a}$ & 9.33 & 12.04 & $4.54 \mathrm{a}$ & $3.60 \mathrm{~b}$ & 21.55 & 22.06 \\
\hline Apseronski & 0.10 & 0.25 & $8.02 \mathrm{~b}$ & $10.67 \mathrm{a}$ & $5.08 \mathrm{a}$ & $3.72 \mathrm{~b}$ & 18.51 & 16.82 \\
\hline Ben Ivey & 0.08 & 0.19 & 8.12 & 8.79 & $4.26 \mathrm{a}$ & $3.04 \mathrm{~b}$ & 20.67 & 19.09 \\
\hline Chiva & 0.07 & 0.07 & 9.31 & 9.30 & $5.70 \mathrm{a}$ & $4.03 \mathrm{~b}$ & 21.51 & 20.62 \\
\hline Early Wonderful & 0.07 & 0.06 & 10.72 & 9.75 & $4.26 \mathrm{a}$ & $2.73 \mathrm{~b}$ & 22.46 & 20.92 \\
\hline Kandahar & 0.02 & 0.39 & 8.47 & 10.21 & 4.78 & 3.73 & 21.03 & 17.94 \\
\hline Kazake & $0.11 \mathrm{~b}$ & $0.65 \mathrm{a}$ & $7.03 \mathrm{~b}$ & $9.29 \mathrm{a}$ & 5.38 & 3.88 & $18.32 \mathrm{a}$ & $14.57 \mathrm{~b}$ \\
\hline Kunduzski & $0.12 b$ & $0.45 \mathrm{a}$ & $7.70 \mathrm{~b}$ & $10.37 \mathrm{a}$ & 4.34 & 5.35 & $18.39 \mathrm{a}$ & $16.03 \mathrm{~b}$ \\
\hline Larry Ceballos 1 & 0.07 & 0.13 & 7.93 & 9.57 & 4.26 & 4.23 & 20.44 & 19.95 \\
\hline ML & 0.02 & 0.10 & 9.88 & 9.93 & 4.42 & 3.13 & 23.43 & 21.20 \\
\hline Mollar & 0.01 & 0.07 & $7.63 \mathrm{~b}$ & $10.80 \mathrm{a}$ & 4.87 & 4.93 & 15.94 & 16.36 \\
\hline Surh-Anor & $0.04 \mathrm{~b}$ & $0.34 \mathrm{a}$ & 7.63 & 9.51 & $4.55 \mathrm{~b}$ & $6.18 \mathrm{a}$ & 16.88 & 18.13 \\
\hline Utah Sweet & $0.08 \mathrm{~b}$ & $0.15 \mathrm{a}$ & 9.54 & 9.50 & 5.55 & 4.94 & 22.46 & 24.01 \\
\hline Wonderful & $0.02 \mathrm{~b}$ & $0.21 \mathrm{a}$ & 8.75 & 10.12 & 4.78 & 6.73 & 20.74 & 22.47 \\
\hline Mean (CV) & $0.07(61.6 \%)$ & $0.28(73.8 \%)$ & $8.56(11.7 \%)$ & $10.03(9.0 \%)$ & $4.76(10.4 \%)$ & $4.49(32.4 \%)$ & $19.90(11.1 \%)$ & $19.16(12.8 \%)$ \\
\hline
\end{tabular}

${ }^{\mathrm{z}}$ Means with different lowercase letters within a row for the same variable are significantly different between treatments by Student's $t$ test at $P<0.05$.

salinity (Karimi and Hassanpour, 2014, 2017; Khayyat et al., 2014, 2016; Naeini et al., 2004, 2006; Okhovatian-Ardakani et al., 2010). The $\mathrm{Cl}$ content in pomegranate leaves was also less than in other woody plants, such as rose rootstocks (Rosa $\times$ hybrida 'Dr. Huey', R. ×fortuniana, R. multiflora, and $R$. odorata) at an EC of 8.2 $\mathrm{dS} \cdot \mathrm{m}^{-1}$ (Niu and Rodriguez, 2008), Sophora secundiflora at an EC of $6.0 \mathrm{dS} \cdot \mathrm{m}^{-1}$ (Niu and Rodriguez, 2010), and Jatropha curcas at an EC of $3.0 \mathrm{dS} \cdot \mathrm{m}^{-1}$ or greater (Niu et al., 2012). These results indicate that pomegranate plants are capable of restricting either the uptake or transport of $\mathrm{Cl}$ (Karimi and Hassanpour, 2014, 2017).

Salinity dominated by $\mathrm{Na}$ salt reduces $\mathrm{Ca}$ availability, transport, and mobility to growing regions of the plant, which subsequently affects the quality of both vegetative and reproductive organs (Grattan and Grieve, 1999). In our study, $64 \%$ of pomegranate cultivars in salt treatment had a significant or a slight decrease in $\mathrm{Ca}$ concentration, which agreed with the results of Khayyat et al. (2016). Salinity dominated by $\mathrm{Na}$ salts also reduces $\mathrm{K}$ acquisition (Grattan and Grieve, 1999;
Hasegawa et al., 2000). Thirteen of 22 pomegranate cultivars in salt treatment had a significant or slight reduction in leaf $\mathrm{K}$ content. This is probably a strategy for plants to reduce salt stress, as K plays an important role in adjusting the osmotic potential of plant cells, as well as activating enzymes related to respiration and photosynthesis (Taiz and Zeiger, 2015). In our study, we observed that $41 \%$ of pomegranate cultivars tended to increase leaf $\mathrm{K}$ content, which agreed with the results of Karimi and Hassanpour (2014) and Naeini et al. (2004). 


\section{Conclusions}

Pomegranate plants are very tolerant to a saline water up to an EC of $15.0 \mathrm{dS} \cdot \mathrm{m}^{-1}$ with little foliar salt damage and slight growth reduction. Like previous reports, pomegranate plants are capable of restricting either the uptake or transport of $\mathrm{Na}$ and $\mathrm{Cl}$ to leaves to reduce salt damage. Pomegranate plants can be grown in hot, arid and semiarid regions, and irrigated with saline groundwater with high salinity. Future research to quantify the effect of salinity on fruit yield and quality is needed.

\section{Literature Cited}

Altland, J.E., J.C. Locke, and C.R. Krause. 2014 Influence of pine bark particle size and $\mathrm{pH}$ on cation exchange capacity. HortTechnology 24:554-559.

Bhantana, P. and N. Lazarovitch. 2010. Evapotranspiration, crop coefficient and growth of two young pomegranates (Punica granatum $\mathrm{L}$.) varieties under salt stress. Agr. Water Mgt. 97:715-722.

Cai, X., Y. Sun, T. Starman, C. Hall, and G. Niu. 2014. Response of 18 Earth-Kind ${ }^{\circledR}$ rose cultivars to salt stress. HortScience 49:544-549.

Carter, C.T. and C.M. Grieve. 2006. Salt tolerance of floriculture crops, p. 279-287. In: M.A. Khan and D.J. Weber (eds.). Ecophysiology of high salinity tolerant plants. Springer Science + Business Media, Dordrecht, the Netherlands.

Castle, W.S., J.C. Baldwin, and M. Singh. 2011. Pomegranate in Florida for commercial enterprises and homeowners. Proc. Annu. Meet. Fla. State Hort. Soc. 124:33-40

Cavins, T.J., B.E. Whipker, and W.C. Fonteno. 2008. Pourthru: A method for monitoring nutrition in the greenhouse. Acta Hort. 779.289-297.

El-Khawaga, A.S., E.M.A. Zaeneldeen, and M.A. Yossef. 2013. Response of three pomegranate cultivars (Punica granatum L.) to salinity stress. Middle East J. Agr. Res. 1(1):64-75.

Gabriel, M., J.E. Altland, and J.S. Owen, Jr. 2009. The effect of physical and hydraulic properties of peatmoss and pumice on Douglas fir bark based soilless substrates. HortScience 44:874-878.

Gavlak, R.G., D.A. Horneck, and R.O. Miller. 1994. Plant, soil, and water reference methods for the western region. Western Regional Extension Publication (WREP) 125. University of Alaska Extension Service, Fairbanks.

Grattan, S.R. and C.M. Grieve. 1999. Salinitymineral nutrient relations in horticultural crops. Scientia Hort. 78:127-157.

Hasanpour, Z., H.R. Karimi, and S.H. Mirdehghan. 2015. Effects of salinity and water stress on echo-physiological parameters and micronutrients concentration of pomegranate (Punica granatum L.). J. Plant Nutr. 38:795-807.

Hasegawa, P.M., R.A. Bressan, J.K. Zhu, and H.J. Bohnert. 2000. Plant cellular and molecular responses to salinity. Annu. Rev. Plant Physiol. Plant Mol. Biol. 51:463-499.
Havlin, J.L. and P.N. Soltanpour. 1989. A nitric acid and plant digest method for use with inductively coupled plasma spectrometry. Commun. Soil Sci. Plant Anal. 14:969-980.

Holland, D., K. Hatib, and I. Bar-Ya'akov. 2009. Pomegranate: Botany, horticulture and breeding, p. 127-191. In J. Janick (ed.). Horticultural reviews 35 . Wiley, Hoboken, NJ.

Isaac, R.A. and W.C. Johnson. 1975. Collaborative study of wet and dry ashing techniques for the elemental analysis of plant tissue by atomic absorption spectrophotometry. J. Assoc. Off. Anal. Chem. 58:436-440.

Karimi, H.R. and Z. Hassanpour. 2014. Effects of salinity and water stress on growth and macro nutrients concentration of pomegranate (Punica granatum L.). J. Plant Nutr. 37(12):19371951.

Karimi, H.R. and H. Hassanpour. 2017. Effects of salinity, rootstock, and position of sampling on macro nutrient concentration of pomegranate cv. Gabri. J. Plant Nutr. 40(16): 2269-2278.

Khayyat, M., A. Tehranifar, G.H. Davarynejad, and M.H. Sayyari-Zahan. 2014. Vegetative growth, compatible solute accumulation, ion partitioning and chlorophyll fluorescence of 'Malas-Saveh' and 'Shishe-Kab' pomegranates in response to salinity stress. Photosynthetica 52(2):301-312.

Khayyat, M., A. Tehranifar, G.H. Davarynejad, and M.H. Sayyari-Zahan. 2016. Effects of $\mathrm{NaCl}$ salinity on some leaf nutrient concentrations, non-photochemical quenching and the efficiency of the PSII photochemistry of two Iranian pomegranate varieties under greenhouse and field conditions: Preliminary results. J. Plant Nutr. 39(12):1752-1765.

Marzolo, G. 2015. Pomegranates. 21 Dec. 2017. $<\mathrm{http}$ ://www.agmrc.org/commoditiesproducts/ fruits/pomegranates/ $>$.

Munns, R. 2002. Comparative physiology of salt and water stress. Plant Cell Environ. 25:239250 .

Munns, R. and M. Tester. 2008. Mechanisms of salinity tolerance. Annu. Rev. Plant Biol. 59:651-681.

Naeini, M.R., A.H. Khoshgoftarmanesh, and E. Fallahi. 2006. Partitioning of chlorine, sodium, and potassium and shoot growth of three pomegranate cultivars under different levels of salinity. J. Plant Nutr. 29:1835-1843.

Naeini, M.R., A.H. Khoshgoftarmanesh, H. Lessani, and E. Fallahi. 2004. Effect of sodium chlorideinduced salinity on mineral nutrients and soluble sugars in three commercial cultivars of pomegranate. J. Plant Nutr. 27(8):1319-1326.

Niu, G. and R.I. Cabrera. 2010. Growth and physiological responses of landscape plants to saline water irrigation: A review. HortScience 45:1605-1609.

Niu, G. and D.S. Rodriguez. 2006. Relative salt tolerance of selected herbaceous perennials and groundcovers. Scientia Hort. 110:352-358.

Niu, G. and D.S. Rodriguez. 2008. Responses of growth and ion uptake of four rose rootstocks to chloride- or sulfate-dominated salinity. J. Amer. Soc. Hort. Sci. 133:663-669.
Niu, G. and D.S. Rodriguez. 2010. Salinity tolerance of Sophora secundiflora and Cercis canadensis var. mexicana. HortScience 45:424 427.

Niu, G., D. Rodriguez, M. Mendoza, J. Jifon, and G. Ganjegunte. 2012. Responses of Jatropha curcas to salt and drought stresses. Intl. J. Agron. doi: 10.1155/2012/632026.

Niu, G., T. Starman, and D. Byrne. 2013. Responses of growth and mineral nutrition of garden roses to saline water irrigation. HortScience 48:756-764.

Okhovatian-Ardakani, A.R., M. Mehrabanian, E. Dehghani, and A. Akbarzadeh. 2010. Salt tolerance evaluation and relative comparison in cuttings of different pomegranate cultivars. Plant Soil Environ. 56(4):176-185.

Qadir, M., A. Tubeileh, J. Akhtar, A. Larbi, P.S Minhas, and M.A. Khan. 2008. Productivity enhancement of salt-affected environments through crop diversification. Land Degrad. Dev. 19:429-453

Strasser, R.J., A. Srivastava, and M. TsimilliMichael. 2000. The fluorescence transient as a tool to characterize and screen photosynthetic samples, p. 445-483. In: M. Yunus, U. Pathre, and P. Mohanty (eds.). Probing photosynthesis: Mechanisms, regulation and adaptation. Taylor and Francis, London, UK.

Strasser, R.J., M. Tsimilli-Michael, and A. Srivastava. 2004. Analysis of the fluorescence transient, $p$. 321-362. In: G.C. Papageorgiou and Govindjee (eds.). Chlorophyll fluorescence: A signature of photosynthesis. Advances in photosynthesis and respiration series. Springer, Dordrecht, the Netherlands.

Sun, Y., G. Niu, and J. Masabni. 2015a. Simulated sea water flooding reduces the growth of ten vegetables. HortScience 50:694-698.

Sun, Y., G. Niu, P. Osuna, G. Ganjegunte, D. Auld, L. Zhao, J.R. Peralta-Videa, and J.L. GardeaTorresdey. 2013. Seedling emergence, growth, and leaf mineral nutrition of Ricinus communis L. cultivars irrigated with saline solution. Ind. Crops Prod. 49:75-80.

Sun, Y., G. Niu, and C. Perez. 2015b. Relative salt tolerance of seven Texas Superstar ${ }^{\circledR}$ perennials. HortScience 50:1562-1566.

Taiz, L. and E. Zeiger. 2015. Plant physiology and development. 6th ed. Sinauer Associates, Sunderland, MA.

Wahome, P.K., H.H. Jesch, and I. Grittner. 2001. Mechanisms of salt stress tolerance in two rose rootstocks: Rosa chinensis 'Major' and $R$. rubiginosa. Scientia Hort. 87:207-216.

Wu, S., Y. Sun, and G. Niu. 2016. Morphological and physiological responses of nine ornamental species to saline water irrigation. HortScience $51: 285-290$

Zeng, L., M.C. Shannon, and C.M. Grieve. 2002 Evaluation of salt tolerance in rice genotypes by multiples agronomic parameters. Euphytica 127:235-245.

Živčák, M., M. Brestič, K. Olšovská, and P. Slamka. 2008. Performance index as a sensitive indicator of water stress in Triticum aestivum L. Plant Soil Environ. 54(4):133139 